\title{
State philanthropy: The demise of charitable organisations in Botswana
}

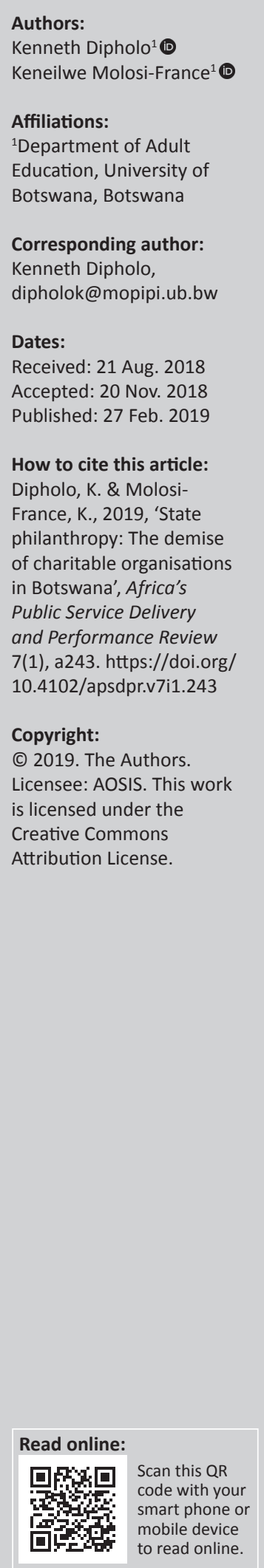

Background: Charitable organisations just like other constituents of the civil society are a vital partner to the governments. Charities provide essential services that positively impact the lives of citizens. Some charities have lobbying functions and the considerable international influence necessary to facilitate social change. Their contribution to the economic, social and political sectors of a nation is widely recognised and governments are expected to create the circumstances in which charities would continue to flourish and fulfil their obligations. However, the quest by charities to partner with governments has always proved inexplicably uneasy and full of twists and turns.

Aim: This study conducted a literature review hypothesising that while the Botswana state will continue to play a role in the protection and promotion of the economic and social wellbeing of its citizens, strong state involvement in charity work fundamentally strikes at the very heart of the life of charitable organisations.

Setting: This study conducted a review of literature on charities in Botswana positing that while charities are expected to work without direct governmental involvement, many have been subjected to state regulation and crippling state control measures. In the context of a developmental welfare state such as Botswana which has lately acquired a philanthropic character, it is argued that charitable organisations are increasingly becoming irrelevant and risk losing public trust that undergirds their core mandate of relieving suffering and providing essential services. A consequence of this would be a return to a stronger state that leaves little room for non-state actors to effectively influence social change.

Methods: This study conducted a review of literature on the operations of charities in Botswana in comparison with international practices in order to dissect similarities and abnormalities that have a bearing in the legitimate and universal mandate of Botswana's charitable organisations.

Results: Three key issues emerged from this study. First, it has been discovered state philanthropy threatens to render charities obsolete. Secondly, it has been discovered that most charities have allowed themselves to operate as extended arm of the state hence are dependent on the state for their operations. As corollary of the preceding discoveries, the study maintains that for their survival, Botswana charities must recalibrate and reposition themselves in order to remain relevant.

Conclusion: The article concludes that widespread state philanthropy championed by the Head of State threatens to relegate and render charitable organisations virtually irrelevant and redundant unless they re-engineer themselves.

\section{Introduction}

It is commonly held that in a welfare state, it may not really matter how activities of voluntary giving are initiated and implemented because focus is on making a contribution in terms of relief of the poor, aged or impotent. Whereas philanthropy is founded on the basis of helping the underprivileged, it is nevertheless important to examine its guiding principles, particularly to understand it from the perspective of the intent of giving to others and the manner of channelling such generosity precisely because philanthropy is connected to certain conceptions of how society should be organised (Ostrower 1995). This is so because people and institutions may decide to give for varying reasons. Philanthropists may give in order to receive benefits, in which case they will be motivated by a desire for personal prestige rather than compassion to help. Thus, philanthropy can be a form of public relations to promote one's image and brand. Ostrower (1995) opines that all philanthropy does have a payback, if not in kind, then in sort. Consequently, the choice to either support charitable organisations or directly support individuals explains the nature of organisation 
of society and the motive for giving. This distinction further differentiates philanthropy from welfare because in giving directly to individuals, donors desire to get some powerful advantage and pursue own interests. Essentially, this style of giving is often done for status-related reasons.

Philanthropy means different things to different cultures. Nevertheless, a common thread is that philanthropy represents activities of voluntary giving and serving beyond one's own family (Leys 2010; Ostrower 1995). In some instances, philanthropy is defined as the investment of private capital for public benefit (David et al. 2014). For the purpose of this discussion, philanthropy is defined as the practice of private individuals or organisations giving money and other resources to public causes. State philanthropy then is to be understood as the practice of the state or state officials giving to individuals and communities. Philanthropy and charity are often used synonymously even though they do not exactly mean the same thing. Charity often relates to meeting immediate needs such as aid in the event of a natural disaster like floods. Thus, charity is essentially reactive, whereas philanthropy is most often proactive and outcomeled (Leys 2010). Traditionally, the practice of philanthropy was founded on supporting voluntary organisations and promoting private initiative rather than direct involvement of the state or state officials in charity activities.

When in April 2008, Lieutenant General Seretse Khama Ian Khama began to serve as Botswana's fourth president, the practice of giving money and other resources to public causes experienced a marked shift from supporting charitable organisations to one of directly giving to individuals.

This article contends that since the ascendancy of Seretse Khama Ian Khama to the presidency of the Republic of Botswana in 2008, there has been a steady trend towards centralisation - with the state or state officials getting directly involved in charity or personalisation - wherein the state president was directly involved in giving to the less fortunate members of the society. While Botswana has always prided herself in helping poorer sections of the society with a variety of tailored goods and services, these were always largely channelled to existing charitable organisations such as the Red Cross for onward distribution to needy members. However, Botswana's fourth president, Seretse Khama Ian Khama, unofficially introduced a new age of philanthropy where the state, in particular the state president, is directly in charge of giving to individuals for political convenience as discussed in details under 'Paradigm shifts: Moving forward and backward?' in this article.

The introductory part of the article contextualises the discussion by positing that charities provide essential services that impact the lives of the less fortunate in many different ways. However, the motive of getting directly involved in giving to individuals seems mischievous (Dipholo \& Molebatsi 2017). The next section situates the social policy agenda in Botswana noting that as a welfare state, giving has always been a norm though the motive for giving seems to have radically changed. The section is followed by the discussion that charitable organisations in Botswana face collapse in the wake of strong direct state involvement in charity work. A conclusion is provided to bring out the main issues discussed.

\section{The important role of charitable organisations}

The provision of social services constitutes an integral part of a country's welfare system. Having embarked on the provision of social services since attaining independence in 1966, Botswana can be classified as an established welfare state in the sense of the centrality of the role of the state in protecting and promoting the economic and social well-being of its citizens (Seekings 2017). This strong and long-standing state commitment to social protection is underscored by the conception of variety of programmes such as the Destitute Programme, Feeding Programme, Old Age Pension Programme and others targeting poorer sections of the population. At the same time, civil society was gradually finding its feet in the provision of social services, culminating in the birth of charitable organisations. The involvement of the civil society in charity was founded on the basis of an appreciation that the state has multiple responsibilities that makes it imprudent for it concern itself with the provision of philanthropy. In effect, charitable organisations, those organisations that have been founded for the purpose of carrying out functions relating to charity, stepped in to provide support in other areas that the state could not adequately support. It is noted that there are generally different role players in any economic milieu often categorised into three key sectors, being public, private and non-profit. However, the non-profit sector that represents civil society has often been relegated to the margins to the extent that they were regarded as insignificant stakeholders. Yet, given the reality of poverty in several countries, especially in Africa, it is no wonder that charitable organisations as a third community sector are essential.

Critiques of the welfare state often hold that charitable organisations and their volunteer activities are unimportant and of little consequence to a country's economic system. However, charitable activities make an important contribution to the economic, social and political sectors of a nation. In fact, the role of charitable organisations and volunteer work is no less important than the roles of the public and private sectors (http:/ /www.arabnews.com).

Charities provide essential services that positively impact the lives of citizens, such as building schools, orphanages like SOS children's villages and religious centres like Ray of Hope. Such organisations provide care and hope for those struggling with crime, addiction, HIV/AIDS, and also provide care for children who have lost parental care (http: / / www.arabnews.com).

Additionally, charitable organisations are a vital partner to the government in many aspects, including personal empowerment and training, fighting poverty, combating 
social challenges such as drug abuse, and attempting to narrow the deep divide between the rich and poor. For instance, Nkaikela Youth Group was established along these lines to bridge the gap and provide HIV/AIDS awareness and mitigation to vulnerable populations and support female sex workers (http://www.arabnews.com).

Charitable and volunteer work is also the safety valve and supporting pillar for a country's security because of the preventive roles it plays especially in fighting extremism, radicalism and criminal acts against humanity. Such work is especially targeted at those who are particularly vulnerable to crime owing to their poverty and harsh living conditions (http:/ / www.arabnews.com).

Palyvoda (2012) opines that charitable organisations as the third community sector are indispensable because charitable groups are beholden, not only in delivering public services to the poor and needy but also in influencing other societal sectors to contribute to such altruistic pursuits in relevant service areas.

Charities comply with corporate governance in terms of professionalism, good management, performance and management evaluation, accountability and transparency in all activities. In this way, they are able to fulfil their obligation within the framework of transparency and compliance with society, the economy and government (Faber \& McCarthy 2005). Many developed countries such as the United Kingdom have begun to promote charities to relieve the government of some of its heavy financial obligations (David et al. 2014). Thus, the British government has sought to partner with charities to meet common economic and social goals in terms of unemployment, security, poverty, drugs and other important issues. Charitable organisations generally have the primary function of giving benefit to the public, especially poorer communities, by performing worthy causes that assist them, directly or by helping community groups. As they are often complementing government's efforts in improving the society, their activities are expected to be in tune with the general public policy or development initiatives.

\section{Botswana as a developmental welfare state}

Botswana attained statehood in 1966, a chronically poor country to the point of being classified as one of the poorest countries in the world (Harvey \& Lewis 1990). Yet from 1966 to the early 1990s, Botswana experienced the 'most rapid rate of growth of GNP per capita (8.3\%) of any country in the world' (Harvey \& Lewis 1990:1), owing to the discovery of minerals. This fortune allowed the economy to generate revenue needed to alleviate rural poverty, culminating in a deliberate policy agenda that focused on the provision of social services to improve quality of life of citizens, especially those living in the rural areas. Since then, Botswana has nurtured a strong and long-standing commitment to stateled social protection, targeting vulnerable and excluded groups (http://www.wahenga.net). This invariably led to the emergence of a strong developmental state, defined as one in which the state is the primary agent of socio-economic change and actively organises and directs it (Edge 1998:333). In essence, a developmental state is characterised by having a strong state intervention in the promotion of national development and social protection. White (1992) categorises a developmental state as representing the state in its developmental capacity: those specific institutions, ideas and policy interventions which embody the socio-economic aims and actions of a given state. In respect of Botswana, Tsie (1996) comments that:

Since independence its bureaucratic and political elites have pursued a series of policies calculated to promote economic growth and development. In the process both elites acquired a developmental orientation. The bureaucratic elite in Botswana are powerful and generally effective in formulating and executing development policy. As a result, much of development that has occurred in Botswana has been state sponsored and directed. It is in this sense that one can speak of a developmental state in Botswana. (p. 601)

The Botswana state takes a leading role in the development process to a point where it could be characterised as an authoritarian government directing state machinery at every instance. The government spends roughly $40 \%$ of Gross Domestic Product (GDP) on social development and education, which is the highest figure in Africa and even above the average for high-income countries (Acemoglu et al. 2003:85). It has to be noted that social development is part and parcel of wider goal of national development within the broad framework of a developmental state. However, a powerful and authoritarian state that is at the centre of every major development initiative is bound to become insensitive, repressive and domineering as to usurp the space naturally reserved for other partners in the development process such as civil society organisations. This could result in co-option of non-state actors leading to their inability to effectively discharge their mandate or at worst their disappearance, resulting in higher levels of poverty, especially among social groups that are underprivileged and dependent on handouts.

In spite of being authoritarian, Botswana's welfare state has continued to support the poor and the marginalised sections of the population through a variety of social programmes that provide basic needs to poorer sections of the population. This state-led social protection programming points to social security as a national priority in Botswana. Social security is defined as:

A system of assistance guaranteed by the state, granted to people in need when their normal source of income has been interrupted or ended ... It could entail assistance to certain disadvantaged groups or supplementing the incomes of pensioners. (Barker \& Holtzausen 1996:138)

Relatedly, the Southern African Development Community (SADC) Code defines it as public and private or mixed public and private measures designed to protect individuals and 
families against income insecurity caused by contingencies such as unemployment, employment injury, maternity, sickness, invalidity, old age and death (Southern African Development Community [SADC] 2004).

Botswana's national vision, Vision 2036, undertakes that Botswana will continue to ensure social inclusion, which is central to ending poverty and fostering shared prosperity as well as empowering the poor and marginalised people (Republic of Botswana 2016). The Vision states that social protection will continue to be provided to support the most vulnerable members of society. The nation's Vision 2036 further comments that by 2036 Botswana will have succeeded in helping people to escape from the poverty trap and that there will be a social safety net for those who find themselves in poverty for any reason and this will go hand in hand with provision of good quality social security, in partnership with the private sector and non-governmental organisations, aimed at vulnerable groups such as the elderly, people with disabilities, orphans and terminally ill. This state commitment to providing for the underprivileged led to the conception of a variety of social programmes such as feeding programmes, the Destitute Programme, State Old Age Pension and Ipelegeng.

\section{Feeding programmes}

Botswana Government feeding programmes have a long history and fall into two categories: school feeding and vulnerable group feeding. Under the school feeding programme, meals are provided to all learners attending government primary and secondary schools. Children at primary schools receive one cooked meal per day at school or two meals if they are remote area children. These are children whose parents live in isolated rural communities characterised by high levels of poverty, comprising mainly people of the San origin. Resident students or boarding students at secondary schools receive three meals daily (Republic of Botswana 2001). The vulnerable group feeding programme provides take-home food rations provided at state-owned health clinics to all children aged 6-60 months, with ration packages designed separately. Take-home rations are also distributed through clinics to selected pregnant and nursing women and to tuberculosis outpatients. While the feeding programmes seek to relieve short-term hunger among the beneficiaries, they are by and large an integral component of the state's household food security strategy (Republic of Botswana 2001).

\section{Destitute Programme}

According to the Revised National Policy on Destitute Persons, a destitute person is 'an individual who due to disabilities or chronic health condition, is unable to engage in sustainable economic activities and has insufficient assets and income sources' (Republic of Botswana 2002). Each qualifying adult in a household can be registered as a destitute. A destitute is a person who owns not more than four livestock units or has an income of less than P120/ month without dependants or less than P150/month with dependants. Registered destitute are eligible for a monthly food basket providing at least 1750 calories per day, plus extra rations for dependants, plus a cash allowance. Shelter is also provided. Destitute persons are also exempted from payment for public services such as water, electricity, school and medical fees, and they are entitled to assistance with basic shelter where necessary. The destitute programme essentially provides psychological support to underprivileged members of the community, needy students and destitute persons.

\section{Old age pension}

The state old age pension was introduced in 1996 and is paid monthly to all citizens aged 65 or above. Payment is made by bank transfer or in cash, in the latter case at a post office or on presentation of a pension order book. Its objective is to provide financial security to elderly citizens who otherwise are without means of support because of the disintegration of the extended family support system (Republic of Botswana 2005).

\section{World War II veterans allowance}

This is a universal entitlement paid on a monthly basis to each World War II veteran or his surviving spouse or children less than 21 years of age on a monthly basis as a token of appreciation for their efforts and sacrifice in contributing towards saving the world from racist domination (Republic of Botswana n.d).

\section{Ipelegeng}

This programme was initially under the drought relief programme to provide social protection against poverty during a drought period. The initial labour intensive public works programme had two components, being the drought relief and the permanent component (Republic of Botswana 2009). The overall objective of Ipelegeng is to provide relief while at the same time carrying out essential development projects that have been identified and prioritised through the normal development planning process. The drought relief programme was intended to provide short-term employment support for citizens during the drought period and as such the levels of wages paid were specifically set at supplementary level for a six-hour working day. Moreover, the programme was self-targeting and designed to maximise employment of simple tools, unskilled and semi-skilled labour to construct or maintain public facilities. The permanent component was funded during non-drought years and operated at a very low key covering both rural and urban areas.

\section{Paradigm shifts? Moving forward and backward}

In spite of the Government of Botswana's long-standing commitment to providing social protection, in the late 1920s government started embracing neo-liberal ideas of a state as 
a facilitator rather than a key player in economic development (Nthomang 2007). This implies that the government embraced and identified the private sector as an engine of economic growth and development. In consequence, this means that the role and influence of the state was reduced, thereby opening up space for the participation of other role players in the provision of social services. By extension, this effectively meant a marked shift in the social and economic framework for the development and actualisation of social policies in the future.

While the government did not abandon its social policy agenda, it nonetheless shifted emphasis from being a strong developmental state built upon guaranteeing financial and food security to citizens to being an enabling player. This shift in emphasis has profound effects on the operations of other role players, particularly the role of charitable organisations in the provision of essential social services. The shift created an enabling environment for the participation of charitable organisations and deeper commitment to philanthropy. This was a defining moment in the lives of charitable organisations - a new lease of life and an opportunity to showcase their capabilities as developmental stakeholders, especially in the area of giving. This paradigm shift in conjunction with the tough public spending environment facing the government gave new hopes for the resurgence of charitable organisations.

Unfortunately, when in April 2008, Lieutenant General Seretse Khama Ian Khama began to serve as Botswana's fourth president, government's role in philanthropic activities assumed a new posture. The government completely turned on its head and to a greater extent refashioned social protection programming by markedly getting directly involved in giving to individuals and communities as opposed to focusing on providing support to charitable organisations. For instance, in 2010 the state president set up the President's Housing Appeal for the Needy whose objective is to provide shelter to needy members of Botswana society. This initiative runs parallel to other state efforts conceived long ago to provide shelter to needy households such as the destitute programme discussed earlier in this article. While these actions of the state or the state president still fall within the remit of social policy in so far as they seek to assist disadvantaged groups, they are inherently uncharacteristic of the unpretentious compassionate actions of a state actor and borders on populism (Dipholo \& Molebatsi 2017). While someone does get a house through the President's Housing Appeal, the way in which the initiative has been designed to run parallel to existing practices is laden with mischief, particularly because it seems to make the state president compete with the government in the provision of housing to needy members of the society.

It is in order to state that in many countries such as Botswana where the state president is both head of state and government, he or she is certainly the country's chief executive officer with the immediate responsibility to set out the direction of the government in every sphere. The state president provides overall strategic guidance to government. In this context, the state president has a personal influence in the policy-making process. In a political system such as in Botswana where power is concentrated in the presidency, the incumbent becomes the leading political personality resulting in a situation where state institutions kowtow. Article 48 (1) of the Botswana Constitution provides that:

... the executive power of Botswana shall rest in the President ... [who shall] act in his own deliberate judgment and shall not be obliged to follow the advice tendered by any other person or authority. (Republic of Botswana 1966:21)

Significantly, the president is the commander-in-chief of the armed forces; he appoints all cabinet ministers and assistant ministers; he appoints the vice-president; he appoints judges of the High Court; he may exercise the prerogative of mercy and may withhold assent to any Bill; he can dissolve and so forth. Ultimately, it could be argued that whereas Botswana is a parliamentary republic, the powers given to the president by the national constitution ensure a presidential form of government (Dipholo \& Molebatsi 2017). In effect, the state president becomes synonymous with the state and by extension, with the development process. Initiatives often have to bear the image of the state president to make it clear that the decision and/or initiative is his or her brainchild. In the context of this article, what it implies is that philanthropic activities such as the President's Housing Appeal for the Needy that bore the seal of the state president are in actual fact personal choices of the state president, which perhaps explains why the handing over of houses sourced through the president's Housing Appeal must, as much as possible, be preceded by the president himself and be broadcast widely in state media.

\section{Why charitable organisations in Botswana will wither away}

In the manner in which the Botswana state has refashioned social protection programming and implementation, by markedly getting directly involved in giving to individuals and communities as opposed to focusing on providing support to charitable organisations, it can be said that the state has now taken the operational space of charitable organisations. Youngman (2000) comments that:

From the perspective of neoliberalism, the idea of civil society is synonymous with its project of reducing the state... In sum, in the tradition of liberalism, civil society is the domain in which individuals can exercise their rights as citizens and set limits to the power of the state. (p. 202)

In accordance with the neo-liberal ideas of the state as a facilitator rather a key player in socio-economic development (Youngman 2000), it is expected that the Botswana state should be working towards developing capable voluntary organisations rather than emaciating or colonising them by 
usurping their space and diverting meagre resources from the private sector towards state philanthropic activities. The role of government in charity essentially subverts the democratic process conducive to the operations of the third sector and by extension marginalises charitable organisations. The direct involvement of the state or state president in charity breeds an unhealthy competition between the state itself and other organisations involved in charity. Under these circumstances, it is likely that the state would choose to legitimise its role in charity in order to remain relevant to the ordinary people and/or enhance its visibility at the expense of its competitors and invariably crowd them out by outmanoeuvring them.

The direct involvement of the state in giving drowns out charitable organisations because, while giving is a voluntary undertaking, it does have a payback, in kind or in sort (Faber \& McCarthy 2005; Magat 1989; Ostrower 1995). Thus, individuals and private companies are likely to divert their contributions to state-led charitable activities where they can maximise publicity and/or enhance their visibility. For instance, in respect of the President's Housing Appeal for the Needy, a register of pledges is published regularly and names of those who contribute are disclosed in the state-owned daily newspaper. While it is stated that this is to inform the public of progress made, the effect could as well be to arm twist private entities to pledge or risk being singled out and marginalised for not heeding the state president's appeal for donations. The effect of this could be that private institutions which have been supporting charitable organisations may have to redirect their assistance towards the state's philanthropic activities in order to get comparable mileage in terms of state favours, publicity and visibility.

Many charities are dependent on statutory funding for a considerable percentage of their income. This means that the entry by the state into charity is likely to negatively affect their revenue because their erstwhile source of income is likely to dry up as the state directly funds its charitable activities and private agencies re-direct their donations to state-led activities ostensibly to seek favours from the state. Alternatively, the state could choose to continue to financially support charitable organisations, but in order to ensure that the state-led charitable activities are not drowned by voluntary organisations' projects, the state may subject them to a harsh accountability regimen with the intention to control, micromanage and / or co-opt them. This will have the effect of making charitable organisations accountable to the state and/or becoming mired in bureaucracy, with statestyled reporting lines, resulting in a complete loss of faith in charitable organisations by the public and erosion of the good will the public has invested in them.

A consequence of this arrangement is that charitable organisations will become affiliates of the state. Thus, state involvement in charity has the potential to co-opt charitable organisations into institutional processes in which they kowtow to the state, specifically in terms of pursuing state-preferred or politically motivated charitable activities that may be outside the immediate mandate of charity organisations. This development stifles innovation in the sense that it narrows the ability of charitable organisations to think outside the box, hence perpetuating the status quo. The development also promotes mono-culturalism in the sense that the state could decide to financially support only charitable organisations that abide by its wishes and makes charitable organisations, if they continued to operate at all, part of the problem they were established to address. Charitable organisations need to work independently of the state or without direct governmental involvement (http:// www.arabnews.com) to enhance the variety of services provided to poor people, with the government simply providing requisite support to voluntary organisations involved in charity. It stifles citizen participation and enthusiasm for private initiatives through channels outside government (Ostrower 1995).

It has to be noted that this discussion is not entirely against the idea of the state's involvement in giving but rather it queries the state's decision to directly give to individuals instead of supporting existing charitable organisations established for this purpose. While it can be argued that it matters little whatever the motivation for giving as long as the end result is a good one, it still has to be borne in mind that philanthropy is a social institution that takes on meaning in the context of a cultural emphasis on individualism and private initiative and a mistrust of governmental power (Ostrower 1995), hence the need for the state to leave charity to charitable organisations. Thus, charitable work should be undertaken within the confines of cultural appropriateness and the framework of proper ethics of giving, both of which are alien to the state.

\section{Evolve or perish: The need for charities to recalibrate}

The discussion laments the direct involvement of the state, in giving to individuals instead of channelling such goods and services through charitable organisations. Nevertheless, the point is not to argue for a complete marginalisation of the state in charity but rather to argue that direct involvement of the state in charity has the potential to emaciate charitable organisations. This would effectively diminish the role of the third sector of society and render charities incapable of providing goods and services that the state could not provide because of its multiple responsibilities (Dipholo \& Tshishonga 2013). Yet, it is unlikely that the state could opt for a lesser role in charity mainly because charitable activities offer opportunities for optimising publicity and visibility of politicians. In this regard, charitable organisations must evolve and commit themselves to a paradigm shift that will enable them to be creative and innovative and to think outside the box. They need to summon the courage to persevere in order to survive for the sake of those who desperately need their goods and services. 
Charity organisations need to change the way they operate, particularly their approach to raising funds and engaging the state and donor agencies. It need not be overemphasised that the number of people who will continue to rely on charities for their livelihoods will continue to increase because of increasing levels of poverty (Roser \& Ortiz-Ospina 2018). Thus, the decline in funding, partly as a result of direct state involvement in charity, demands charity organisations to evolve or become exceedingly peripheral and ultimately disappear from the social space. Charities must find ways to diversify their fundraising activities, including finding ways to generate operational and developmental income without necessarily becoming profit-oriented.

Significantly, charities must build their capacity so that they can do things differently with the limited resources they have. They need to develop new skills and upskill their staff so that they utilise available opportunities and also tackle challenges in a rapidly changing economic, social and political environment. Charities need to have well-trained personnel to be able to tap into available opportunities, to adapt to a changing environment, to perform more effectively and efficiently and engage in strategic planning in order that they remain afloat even when the state strays into their operational sphere.

In this instance, some institutions of higher learning offer study programmes that seek to build the capacity of nonstate actors as partners in development. For instance, the Department of the Adult Education (Lifelong Learning and Community Development) of the University of Botswana offers a Diploma in Non-Governmental Organisations (NGO) Management programme by distance learning whose aim is to equip NGO personnel with cognitive and professional competencies that will enhance effective and efficient delivery of services in a globalised and competitive environment.

\section{Conclusion}

Charity is considered to be one of the most significant contributions a person can make to positively change the life of another person. It is an obligation that is part of a compassionate society. It often provides an arena into which efforts of private individuals can be directed and allows individuals to support the causes of interest and importance to them. Whereas it could be argued that charity provides a distraction from the fundamental ills of society (Shapiro 2007) and does little to change the long-term reality of the needy sections of the population, it is nevertheless essential in addressing the immediate needs of poorer people, particularly in respect of providing their basic needs.

It has been argued that the role of voluntary organisations in philanthropic work is justified on account of distrust of governmental power and bureaucracy as well as scepticism about government competence. While the state will always have a role to play in philanthropic work, such involvement should focus more on supporting voluntary organisations and individuals working in charity so that charitable organisations operate in a system that combines philanthropic work and state welfare programmes. This approach accords democratic space for the operations of charitable organisations while at the same time permitting the state to focus on broader welfare policy issues. Philanthropy by the state is associated with social snobbery or governing through money, mainly because state activities are often widely broadcast to inform the public, a development that is seen as being culturally inappropriate, snobbish and humiliating to the recipients.

State philanthropy reflects a symptomatic problem with development policy, specifically indicating that the state has veered off from traditional social welfare provision towards direct involvement in giving in order to present an image of a caring state, as espoused in National Vision 2036.

It is clear that the democratic space for the operations of charitable organisations is shrinking with disastrous consequences. Whether this is a result of political pressures or administrative imperatives, the reality points to a need to protect civic spaces, of course without completely closing out the state. There is a need for a paradigm shift in favour of a bigger role for voluntary organisations in charity work, to reenergise the communities to drive change because they often more readily invest their trust in the civil society.

\section{Acknowledgements}

The University of Botswana provided conference funds to enable the corresponding author to present the article at the South African Association of Public Administration and Management (SAAPAM) conference.

\section{Competing interests}

The author declares that they have no financial or personal relationships that may have inappropriately influenced them in writing this article.

\section{Authors' contribution}

K.D. was responsible for the 'Abstract', 'Introduction', 'Botswana as a developmental welfare state' and 'Why charitable organisations in Botswana will wither away?' sections, while K.M.-F. contributed to the "The important role of charitable organisations', 'Paradigm shifts' and the 'Conclusion' sections. The authors have shared the tasks equitably from the development of the proposal through to the final write-up. However, the corresponding author presented the article at the 2016 SAAPAM annual conference.

\section{References}

Acemoglu, D., Arellano, M. \& Dekel, E., 2013, Advances in economies and econometrics, Cambridge University Press, Cambridge.

Barker, F.S. \& Holtzhausen, M.M.E., 1996, South African labour glossary, Juta Press, Pretoria.

David, K., Pete, B., Joe, H., Véronique, J., Deb, J. \& Gareth, L., 2014, The UK civil society Almanac 2014, NCVO, London. 
Dipholo, K. \& Molebatsi, R., 2017, 'Personalized state: Botswana under Seretse Khama Ian Khama', in L. Amtaika (ed.), Culture, democracy and development in Africa, pp. 347-362, Pan African University Press, Austin.

Dipholo, K. \& Tshishonga, N., 2013, 'Untenable marriage: Situating civil society in Botswana and South African political landscape', Journal of Public Administration 48(1), 51-62.

Edge, W.A., 1998, 'Botswana: A developmental state', in W.A. Edge \& M.H. Lekorwe (eds.), Botswana: Politics and society, pp. 333-348, J.L. van Schaik, Pretoria.

Faber, D.R. \& McCcarthy, D. (eds.), 2005, Foundations for social change: Critical perspectives on philanthropy and popular movements, Rowan \& Littlefield Publishers, New York.

Harvey, C. \& Lewis, S.R., 1990, Policy choice and development performance in Botswana, Macmillan, London.

Leys, D., 2010, The case for encouraging philanthropy, House of Lords Library Note, London.

Magat, R. (ed.), 1989, Philanthropic giving: Studies in varieties \& goals, Oxford University press, Oxford.

Nthomang, K., 2007, Provision of services and poverty reduction: The case of Botswana, United Nations Research Institute for Social Development, Geneva.

Ostrower, F., 1995, Why the wealthy give: The culture of elite philanthropy, Princeton University Press, Princeton.

Palyvoda, L., 2012, Civil society organizations in Ukraine: The state and dynamics, 2002-2011, SILA, Kyiv.

Republic of Botswana, 1966, Constitution of Botswana. Parliament of Botswana, Government Printers, Gaborone.
Republic of Botswana, 2001, Report on the review of primary school menu, Government Printers, Gaborone.

Republic of Botswana, 2002, The revised national policy on destitute persons, Government Printer, Gaborone.

Republic of Botswana, 2005, Guidelines for the provision of social safety nets, Government Printer, Gaborone.

Republic of Botswana, 2009, Guidelines for the implementation of Ipelegeng Programme, Government Printer, Gaborone.

Republic of Botswana, 2016, Vision 2036: Achieving prosperity for all, Lentswe la Lesedi, Gaborone.

Republic of Botswana, n.d., Department of Social Services - Overview, Government Printers, Gaborone.

Roser, M. \& Ortiz-Ospina, E., 2018, Global extreme poverty, viewed 15 November 2018, from https://ourworldindata.org/extreme-poverty.

Seekings, J., 2017, Building a conservative welfare state in Botswana, WIDER Working Paper 2017/83, UNU, WIDER, Helsinki.

Shapiro, D., 2007, Is the welfare state justified?, Cambridge University Press, Cambridge.

Southern African Development Community (SADC), 2004, SADC Code on Social Security. SADC Secretariat, Gaborone.

Tsie, B., 1996, 'The political context of Botswana's development performance', Journa of Southern African Studies 22(4), 599-619.

White, R., 1992, Riding the tiger: The politics of economic reform in post-Mao China, Macmillan, London.

Youngman, F., 2000, The political economy of adult education and development, Zed Books, London. 